\title{
A noção de contrato do Direito Romano à contemporaneidade: uma análise evolutiva do sistema contratual moderno
}

\author{
Ariadna Fernandes Silva* \\ Maria Vital da Rocha*
}

\begin{abstract}
RESUMO: O presente trabalho tem por escopo oferecer uma noção da teoria contratual desde o Direito Romano até a contemporaneidade. Nessa perspectiva, inicia-se com uma análise do sistema contratual romano, por representar a mais importante fonte material do Direito na história do ocidente, visto terem sido os romanos criadores da maioria dos institutos e princípios do Direito Civil. Depois, passa-se ao sistema contratual moderno, desde a Idade Média até nossos dias. Remete-se ao método histórico e sistemático como fonte substancial para se perceber a evolução contratual.
\end{abstract}

PALAVRAS-CHAVE: Contrato; Direito Romano; Evolução; Contemporaneidade; Princípios contratuais.

\section{The notion of Roman law contract to contemporaneity: an evolutionary analysis of the modern contractual system}

\begin{abstract}
The present work has the scope to offer a notion of contractual theory from the Roman Law to the contemporaneity. From this perspective, it begins with an analysis of the Roman contractual system, since it represents the most important material source of law in the history of the West, since the Romans were the creators of most of the institutes and principles of Civil Law. Afterwards, it is transferred to the modern contractual system, from the Middle Ages to our days. It refers to the historical and systematic method as a substantial source in order to perceive the contractual evolution.
\end{abstract}

KEYWORDS: Contract agreement; Roman Law; Evolution; Contemporaneity; Contractual principles.

INTRODUÇÃO

\footnotetext{
* Mestranda em Direito Privado na UNI7, Pós-graduada em Direito e Processo do Trabalho, pela UNICHRISTUS Advogada.

* Doutora em Direito Civil pela USP, Professora da graduação e do programa de graduação da Faculdade de Direito da UFC, Coordenadora da graduação e professora do mestrado da UNI7.
}

Revista Brasileira de Direito Civil em Perspectiva | e-ISSN: 2526-0243 | Maranhão | v. 3 |

n. 2 | p. 01 - 22 | Jul/Dez. 2017. 
O Direito moderno ocidental deita raízes na família romano-germânica, sistema de direito que ultrapassou as fronteiras do antigo Império Romano, para se tornar o maior sistema de direitos conhecido na história da humanidade. Daí, evidencia-se a grande influência do Direito Romano sobre a ordem jurídica ocidental, em especial, no ramo do Direito Civil.

Para melhor visualizar o sistema contratual moderno, faz-se necessário voltar às suas origens, uma vez que qualquer instituto jurídico, objeto de um estudo sistemático, não prescinde de uma análise contextual de sua evolução no decurso da história, por meio do estudo de sua origem e desenvolvimento ao longo do tempo.

Neste trabalho, propõe-se, inicialmente, o desenvolvimento de um estudo histórico e evolutivo da teoria geral dos contratos, no Direito Romano, como origem do instituto, e no Direito moderno e contemporâneo. E, por fim, pretende-se enunciar uma visão da principiologia contratual desde a idade moderna até a contemporaneidade, contrapondo-se, quando possível, com o Direito Romano.

Dessa forma, inicia-se com uma análise história dos contratos no Direito Romano, por representar este a mais importante fonte material do Direito na história do ocidente, e, também, por terem sido os romanos os criadores da maioria dos institutos jurídicos e princípios do Direito Civil.

Na segunda parte, procura-se explorar o sistema contratual moderno e contemporâneo, recorrendo a uma reflexão histórica desde a Idade Média até os dias atuais, para depois discorrer-se sobre os princípios contratuais tradicionais, percorrendo-se a sua evolução até a contemporaneidade, e, enfim, os princípios contratuais modernos.

Para que se retrate com fidelidade o tema em apreço, adota-se o método dialético e histórico de pesquisa, em uma análise histórica e evolutiva da teoria dos contratos. Ainda, será realizada uma pesquisa teórica, em fontes doutrinárias de autores romanistas e civilistas, tais como livros, periódicos e artigos científicos relacionados com o tema em estudo, além da própria legislação nacional, com principal enfoque no Código Civil de 2002 (CC) e na Constituição Federal brasileira de 1988 (CF).

\section{SISTEMA CONTRATUAL ROMANO}


A maior parte do Direito ocidental tem origem na família de direitos romano-germânica, sistema atualmente disperso pelo mundo inteiro, ultrapassando as fronteiras do antigo Império Romano, e conquistando toda a América Latina, grande parte da África, alguns países do Oriente, Japão e a Indonésia. Este sistema foi formado na Europa Continental, desenvolvido pelo renascimento dos estudos do Direito Romano nas Universidades, durante cinco séculos, e, posteriormente pela Escola de Direito Natural, período em que foi dominado pela legislação. ${ }^{1}$

À título de melhor compreensão nesse estudo, urge destacar que a história externa do Direito Romano se divide em períodos, podendo se registrar os seguintes: Realeza (vai das origens de Roma à queda da realeza em 510 a.C); República (de 510 a.C até 27 a.C, quando o Senado investe Otaviano - futuro Augusto - no poder supremo de princeps); Império Principado (de 27 a.C a 285 d.C, com o início do Dominato de Diocleciano); Império Dominado (de 285 d.C a 565 d.C, data em que falece Justiniano). E quanto à história interna, é seguida as seguintes fases: Direito antigo ou pré-clássico (das origens de Roma até a Lei Aebutia aproximadamente entre 149 e 126 a.C); Direito clássico (de 126 a.C até o término do reinado de Diocleciano, em 305 d.C); Direito pós-clássico ou romano-helênico (de 305 d.C até a morte de Justiniano, em 565 d.C - o Direito justinianeu teve vigência, porém, de 527 a 565 d.C). ${ }^{2}$

O Direito das obrigações constituiu uma categoria fundamental nos direitos da família romano-germânica. Obrigação - obligatio - é definida pelas Instituições de Justiniano, como "el vínculo jurídico - iuris vinculum -por el que, necesariamente, somos constreñidos - quo necessitate adstringimur - a pagar alguna cosa - alicuius solvendae rei - según los derechos de nuestra ciudad - secundum nostrae civitate iur.$-^{3}$

O sistema romano se preocupou com as principais classificações das obrigações, na seguinte ordem cronológica, segundo Gutiérrez: nas Instituições de Gaio; no período pósclássico; na época de Justiniano; e nos intérpretes gregos pós-justiniano.

Outrossim, frisa-se que os romanos não chegaram a definir o negócio jurídico, uma vez que a sua mentalidade jurídica era orientada para o concreto, sendo estranha a abstrações. Trataram-se mais genericamente de actus e de actio, que referem uma atividade dirigida à obtenção de um efeito jurídico, mas não constituíram um conceito nem um regime jurídico unitário. O conceito de negócio jurídico foi elaborado pela dogmática moderna, sobretudo pela 
Pandectística, a partir das fontes romanas que reconhecem a vontade como fator determinante da produção de efeitos jurídicos. ${ }^{5}$

Os romanos, dos seus primórdios, até a época da República (27 a.C), foram bastante formalistas, na observação de rígidos esquemas e rituais para as contratações, sob pena de nulidade. ${ }^{6}$ Em uma fase inicial, própria da ius civile, a contratação em Roma estava presidida pelo formalismo. A obrigação nascia, segundo Gaio, pelas palavras - verbis obligatio fit - na forma estabelecida pela lei, e também pela escritura - litteris obligatio fit - não por todo documento escrito, somente pelos modos estabelecidos pelo próprio Direito. ${ }^{7}$

Os contractus, inicialmente, não podiam existir sem uma forma que os exteriorizasse e eram utilizados em três categorias: litteris, que obrigavam a inscrição material no livro do credor; re, os que precisavam da tradição da coisa; e verbis, que necessitavam apenas da troca de expressões orais estritas, tinham uma função religiosa e prática. Nessas categorias, o credor poderia fazer uso de uma ação para exigir o cumprimento da obrigação avençada, pois o Direito Romano não compreendia o significado de direito subjetivo, tal como se tem hoje, concebia apenas a ideia de actio. $^{8}$

No tempo de Gaio, quatro eram as modalidades de contratos: re, litteres, verbis, consenso. Estes últimos apareceram depois, portanto, visualizando-se quatro tipos: venda, locação, mandato e sociedade. ${ }^{9}$ Assim, com o surgimento do consensualismo, nasceram os contratos que se celebravam solo consensu, existindo, inicialmente, em quatro: venda, locação, mandato e sociedade; em que deveriam ser observadas as formalidades previstas. Posteriormente foram criados novos, como os contratos reais (depósito, comodato, mútuo e penhor), e os consensuais (venda, arrendamento, mandato e sociedade), sendo, também, reconhecidos pelo Direito Romano, outros pactos, utilizados para determinados negócios jurídicos.

Em suma, os contratos representavam uma espécie de convenção que, desde a época clássica, geravam obrigações civis por si mesmos; ao contrário dos pactus, que, por não terem uma forma prevista em lei, nem lhes era atribuída a proteção da actio, geravam apenas obrigações naturais (nuda pacta). Os nuda pacta eram utilizados somente para modificar ou extinguir os contratos; se não fossem acessórios de um outro; ou se não recebessem força do Direito Pretoriano ou de alguma Constituição Imperial do período pós-clássico (305 a 565 a.C), casos em que geravam obrigação civil ou principal, eram os pactos legítimos, os pretorianos e 
os adjetos ou acessórios, denominados vestidos (pacta vestita). No Direito pós-clássico, Moreira Alves aduz que, possivelmente:

\begin{abstract}
A tipicidade contratual sofre abalo com a admissão da categoria dos contratos inominados, isto é, contratos atípicos, que formam uma categoria abstrata, e que têm, em comum, a unidade de ação que os tutela e o fato gerador da obrigação: a execução por um dos contratantes, de sua prestação faz nascer, para o outro, a obrigação de efetuar a contraprestação. ${ }^{10}$ (Grifo original)
\end{abstract}

Somente a partir dessa linha evolutiva inicial, que vai até a Codificação de Justiniano, no século VI, é que a vontade vai conseguir ultrapassar as fórmulas solenes, unificando-se, pelo menos em parte, os conceitos de contrato e de convenção. Assim, os romanos desenvolveram e ordenaram os contratos que satisfaziam as exigências de seu cotidiano jurídico. "Em termos genéricos, não se distancia da verdade dizendo que o romano partiu do formalismo original marchando para o consensualismo"11.

No Direito justinianeu, o cenário se modifica totalmente: os juristas bizantinos - em vez que de considerarem que a obrigação nasce do elemento objetivo (forma ou datio rei) como no período clássico - passaram a entender que a obrigação resulta do acordo de vontades, ou seja, o acordo de vontade passa a ser elemento jurídico importante. Entretanto, como bem assevera Moreira Alves, há divergência sobre o que isso significa, no sentido de que alguns autores (Riccobono e Santifilippo) entendem que nesse período vigorava o princípio de que todo acordo de vontade lícito gerava obrigação, com base na Constituição do Imperador Leão, de 472 d.C (C. VIII, 37, 10), acabando-se, totalmente, o formalismo da stipulatio. Outrossim, outros romanistas (Rotondi e Astuti) são negativos a isso, aduzindo que no Direito justinianeu ainda persistem a categoria dos pactos nus, e, portanto, sob certo aspecto, a tipicidade contratual, no sentido continuavam a entender que cada contrato tinha uma figura própria. ${ }^{12}$

Finalmente, com a queda do Império Romano, surgiu a influência do Direito Germânico, que era um Direito marcado pelo simbolismo e menos avançado que o Romano. Essa doutrina de ritualismos vai perdurar até a Idade Média.

\title{
2 SISTEMA CONTRATUAL MODERNO E CONTEMPORÂNEO
}


Com a chegada da Idade Média, ainda sob a influência romana, o Direito Contratual se modifica, em virtude da abolição indireta dos atos sacramentais. "As práticas medievais evoluem para transformar a stipulatio romana na traditio cartae, o que indica a entrega de um documento" 13 , passando a forma escrita a ser predominante entre os negócios. Assim, passa a ser enfatizado o sentido obrigatório do contrato, em virtude da grande influência da Igreja Católica, que valorizava o consentimento, e do estudo romano. Os costumes mercantis passaram a simplificar as formas contratuais, conferindo força obrigatória às manifestações de vontade, sem necessidade de formalidades exageradas.

A consagração do consensualismo, oriundo dos contratos consensuais romanos, não encontrou obstáculos no Direito Contratual moderno. Esse princípio predominou durante o século XIX e avançou pelo século XX, afirmando-se, também, junto com ele, o princípio da obrigatoriedade, retomando-se, assim, a velha máxima pacta sunt servanda. A codificação do século XIX conservou, entretanto, as linhas gerais do Direito Romano e o século XX conservou os mesmos institutos, acrescentando muito pouco. “Em dois mil anos, porém de civilização jurídica romano-cristã pouco se distanciou em termos de tipologia contratual” ${ }^{14}$.

O contrato, portanto, em sua concepção tradicional, era inspirado na liberdade contratual, daí vem sua força obrigatória, não podendo haver intervenção externa em sua órbita. Desta forma, “o jurista de século XIX afirmava, e o do começo do século XX repetia: 'Quem diz contratual diz justo’”15. O liberalismo do século XX consagrou os princípios da autonomia da vontade e o da força obrigatória do contrato. "Na Idade Moderna, a vontade associava-se à autonomia, nascendo, a autonomia da vontade"16.

A conceituação moderna de contrato formou-se devido à confluência de diversas correntes de pensamento, dentre as quais: a) a dos canonistas; b) a da escola do Direito Natural, na linha descrita por Diez Picazo. ${ }^{17}$ Os canonistas contribuíram, por valorizar o consentimento e a fé jurada, abrindo caminho para a formulação dos princípios da autonomia da vontade e do consensualismo. E o Jusnaturalismo, ao defender a vontade livre dos contratantes como elemento suficiente para obrigá-los, conceituava o contrato, como o acordo de vontades, expresso ou tácito, tendo o Direito Natural como base. Tudo isso, constitui-se à luz da ideologia individualista dominante à época da consolidação do capitalismo e do liberalismo econômico. O contrato aparece como um instituto que serve a todos os tipos de relações sociais, para todas as pessoas, sem distinção alguma de condição social. 
A doutrina nascida do Estado Liberal, porém, foi sendo mitigada em razão da necessidade crescente de se restabelecer o equilíbrio econômico entre os contratantes, rompido pelo excesso de poder empresarial advindo da industrialização crescente, do capitalismo e da aplicação demasiada ampla do princípio do consensualismo. Surge daí a convicção de um crescente dirigismo contratual na liberdade e na autonomia da vontade, isso na formação do contrato, pela aplicação de leis de ordem pública, no estabelecimento de cláusulas obrigatórias de interesse público; e no supervisionamento da execução do contrato, dando-se poder ao Judiciário para intervir no restabelecimento da justiça comutativa.

Na verdade, é o nascimento do Estado Social, no final do século XIX e no século XX, intervencionista, que ocasionou uma massificação em todos os setores da sociedade, em especial, o dos contratos, levando a morte do modelo tradicional de contrato e fazendo com que surgissem novas formas, como os contratos de adesão, os necessários e os regulados pela lei.

\footnotetext{
Toda essa revolução mexe com a principiologia do Direito Contratual. Os fundamentos da vinculatividade dos contratos não podem mais se centrar exclusivamente na vontade, segundo o paradigma liberal individualista. Os contratos passam a ser concebidos em termos econômicos e sociais. Nasce a Teoria Preceptiva [...] segundo essa teoria, as obrigações oriundas dos contratos valem não apenas porque as partes as assumiram, mas porque interessa à sociedade a tutela da situação objetivamente gerada, por suas conseqüências econômicas e sociais. ${ }^{18}$
}

Cumpre destacar as fases da teoria do contrato no século XX: "a primeira, da sobrevivência da ideia contratualista clássica; a segunda, da decadência ou do declínio do contrato; a terceira, da retomada de prestígio; e a quarta, do surgimento de novas figuras” ${ }^{19}$.

No Código Civil brasileiro de 1916, subsistiu a mesma tipologia contratual e técnica da Codificação Romana do século VI, com poucas mudanças. Predominava a concepção consensualista romana, que pressupunha igualdade de condições entre as partes, um ideal dificilmente atingido, pois um contrato privado paritário ocupa, ainda hoje, uma parcela pequena no mundo dos negócios, principalmente com o avanço do capitalismo e a multiplicação das relações econômicas que transformou os negócios em contratos de massa, impessoais e padronizados. $^{20}$

O Código Civil de 2002 além de tipificar os contratos tradicionais do código anterior, listou outros. Consagrou os princípios clássicos da força obrigatória, da autonomia da vontade, 
da intangibilidade de seu conteúdo e da relatividade de seus efeitos. E ainda positivou novos, como a função social do contrato (art. 421), a boa-fé objetiva (art. 422) e o equilíbrio econômico do contrato (arts. 157, 478 e 480). Nasce uma nova forma de tratamento do contrato, fruto de todo o desenvolvimento da teoria contratual do século XX, em virtude das exigências da vida social e econômica e da consequente necessidade jurídica. ${ }^{21}$

\section{PRINCÍPIOS INFORMADORES DOS CONTRATOS}

Os princípios básicos que orientam a teoria contratual são esquematizados pela maioria da doutrina, sendo mantido o mesmo conteúdo fundamental, embora haja uma mudança na nomenclatura. Orlando Gomes, por exemplo, considera que o Direito Contratual repousa em quatro princípios - a autonomia da vontade, o consensualismo, a força obrigatória e a boa-fé. ${ }^{22}$ Já Caio Mário destaca a função social do contrato e os princípios da obrigatoriedade, da relatividade e do consensualismo, além da boa-fé objetiva. ${ }^{23}$

A par da existência de vasto rol de princípios, destacam-se, aqui, os seguintes princípios fundamentais da teoria contratual: autonomia da vontade, obrigatoriedade dos contratos, da supremacia da ordem pública, boa-fé contratual, e, por último, a função social do contrato.

\subsection{Princípios contratuais tradicionais: autonomia da vontade ou liberdade contratual, obrigatoriedade dos contratos e supremacia do interesse público}

Desde o período clássico romano, as pessoas têm liberdade para contratar, escolher com quem contratar e o respectivo conteúdo do contrato. Entretanto, a liberdade de contratar teve seu auge na doutrina do liberalismo econômico, nascida com a Revolução Francesa, no século XVIII, em que se fundamentaram as primeiras codificações do século XIX, influenciando a teoria geral do contrato. Nesse período, permitia-se que o individualismo, a liberdade e a igualdade política pudessem se sobrepor à justiça e à solidariedade, daí surgindo a ideia da ampla liberdade de contratar, ou seja, o princípio da autonomia da vontade privada.

Immanuel Kant, no Iluminismo do século XVIII, considerava que a liberdade era algo inato ao homem, na esteira do Iluminismo Racionalista, sendo o homem dotado de uma vontade pura e de uma vontade possível de ser determinada pela lei moral - imperativo categórico -, 
segundo o princípio seguinte: "age de tal modo que a máxima de tua vontade possa valer sempre como princípio de uma legislação universal” ${ }^{24}$. O pensamento kantiano dominou o mundo ocidental, na ideia da razão prática e de autodeterminação do homem como fonte de justiça. ${ }^{25}$

Inspirada no Código Francês, base do sistema individualista, a autonomia da vontade “[...] manifesta-se, por conseguinte, sob tríplice aspecto: a) liberdade de contratar propriamente dita; b) liberdade de estipular o contrato; c) liberdade de estipular o conteúdo do contrato"26, sendo, a ampla liberdade de contratar, uma faculdade conferida aos contratantes de criar relações na órbita do Direito, com autonomia e ampla liberdade, sem qualquer interferência do Estado.

Nessa esteira, a ideia de que os contratos se formavam, em princípio, solo consensu foi afirmada, em definitivo, na modernidade. Assinala Caio Mário, citando um trecho histórico:

\footnotetext{
Quando, pois, no limiar da Idade Moderna, um jurista costumeiro, como Loysel, dizia que os 'os bois se prendem pelos chifres e os homens pela palavra' fazia na verdade, e a um só tempo, uma constatação e uma profissão de fé: testemunhava em favor da força jurígena da palavra em si mesma, e deitava uma regra, segundo a qual os contratos formavam-se, em princípio, solo consenso. ${ }^{27}$ (Grifo original).
}

O princípio do consensualismo impõe que o contrato nasce do acordo de vontades entre os interessados, contrapondo-se ao formalismo e ao simbolismo do Direito Romano. Neste sentido, os contratos são, em regra, consensuais, e, apenas como exceção, são admitidos contratos reais e formais. Predominou em todo o século XIX e avançou pelo século XX até os nossos dias, significando que, o que as partes contratantes estipularem, de comum acordo, deverá ser fielmente cumprido, retomando-se a velha máxima, pacta sunt servanda. Daí decorre o princípio da força obrigatória dos contratos - um contrato válido e eficaz deve ser cumprido pelos contraentes (pacta sunt servanda), tornando a palavra dada irreversível. Essa obrigatoriedade forma a base do Direito Contratual. ${ }^{28}$

O princípio da obrigatoriedade dos contratos, também chamado de força vinculante das convenções, significa que as estipulações contratuais devem ser cumpridas. Pela autonomia da vontade, as pessoas privadas são livres para contrair obrigações, porém, uma vez estipulada uma avença válida e eficaz, a não-observância do acordo mútuo sujeita às partes à responsabilidade contratual, uma vez que a proposta dada obriga o proponente, se o contrário não resultar dos termos dela, da natureza do negócio, ou das circunstâncias do caso. Entretanto, 
o ordenamento jurídico deve conferir às partes instrumentos judiciários para obrigação ao cumprimento das avenças, sob pena de indenização por perdas e danos. "Não tivesse o contrato força obrigatória estaria estabelecido o caos. Ainda que se busque o interesse social, tal não deve contrariar tanto quanto possível a vontade contratual, a intenção das partes”29.

Na concepção clássica, a única limitação encontrada a este princípio era o caso fortuito e a força maior, principalmente à luz da doutrina do liberalismo econômico, que repetia a máxima: “quem diz contratual diz justo”, sendo o contrato “uma espécie de lei privada entre as partes, adquirindo força vinculante igual à do preceito legislativo, pois vem munido de uma sanção que decorre da norma legal, representada pela possibilidade de execução patrimonial do devedor" ${ }^{30}$.

Assinala-se, também, a máxima pacta sunt servanda - os contratos devem ser cumpridos - como fruto da criação do Oitocentos, derivado de um fragmento do Digesto, 2, 14, 1 pr, de Ulpiano: "Quid enim tam congruum fidei humanae quam ea, quae inter eos placuerunt, servare?” , ou seja, o que haverá de mais compatível com a fé humana do que respeitarem, os homens, aquilo que foi por eles pactuado ${ }^{31}$

A interpretação dos contratos deveria ser conduzida ao respeito à manifestação de vontade. Nesse rumo, o Código Civil de 1916 adotou a teoria da vontade como princípio de hermenêutica dos atos jurídicos, em que “o elemento psicológico (o querer íntimo) prevaleceria sobre o elemento objetivo (o texto que veicula a declaração, o sentido literal da linguagem)”32.

Na senda da autonomia de vontade, qualquer pessoa física ou jurídica poderá formular ou não uma manifestação de vontade com intuito de produção de efeitos jurídicos. Nessa perspectiva, alguns do final do século XX estipularam algumas exceções a essa autonomia da vontade, com o objetivo de amenizar o desequilíbrio contratual, em contraposição a plena liberdade existente no século XVIII e XIX. Sendo assim, o Estado garantia a execução dos contratos, se houvesse desrespeito ao pacta sunt servanda. ${ }^{33}$

A autonomia da vontade, todavia, passou a sofrer profundas mudanças, em sua concepção tradicional, por volta do século XX, com a Primeira Guerra Mundial (1914-1918) e a Revolução Russa de 1917, em que se começou a se questionar os valores liberais antecedentes, ou seja, as ideias do Estado Liberal. Nesse período passa-se a considerar o interesse social das avenças, passando o Estado a intervir com mais proeminência nas relações sociais e econômicas, na 
A noção de contrato do Direito Romano à contemporaneidade: uma análise evolutiva do sistema contratual moderno

esteira das Constituições do México de 1917 e Alemã (de Weimar) de 1919, fruto do Estado Social, intervencionista e regulador das realidade econômica e social.

Cumpre destacar, portanto, que com os novos contornos da teoria contratual, em razão do crescente e progressivo dirigismo estatal na economia, a autonomia da vontade passa a consistir a ser mitigada em função de regras impostas pela lei e de interesse geral.

Nessa direção, a liberdade de contratar, como poder de auto-regulamentação dos interesses privados, na linha da autonomia privada, é objeto de restrições pelo princípio da supremacia da ordem pública, que proíbe estipulações contrárias à moral, à ordem pública e aos bons costumes. ${ }^{34}$

As normas de ordem pública, segundo Caio Mario, são as que instituem a família; as da ordem de vocação hereditária e a sucessão testamentária; as de organização política e administrativa do Estado, as de organização econômica; a de direitos fundamentais do trabalho; "enfim, as normas que o legislador erige em cânones basilares da estrutura social, política e econômica da nação"35.

O Código Civil de 2002, em seu art. 2.035, parágrafo único, dispõe que nenhuma convenção prevalecerá se contrariar preceitos de ordem pública, tais como os estabelecidos para assegurar a função social da propriedade e dos contratos. Outras disposições da lei civil, também, evidenciam essa regra moral e jurídica.

Sabe-se que os conceitos de ordem pública e bons costumes variam de um lugar para outro e de uma época para outra, e a lei, por consequência, os acompanha. Dessa forma, o contrato é guiado tanto pela autonomia da vontade, como também se submete à ordem pública. “Certo será então enunciar que em todo o tempo o contrato é momento de equilíbrio destas duas forças, reduzindo-se o campo da liberdade de contratar na medida em que o legislador entenda conveniente alargar a extensão das normas de ordem pública, e vice-versa”36

Em vista disso, no Direito Contratual contemporâneo, a liberdade de contratar está adstrita a limitações de ordem pública, social e também moral. "Assim, o ordenamento procurou dar aos mais fracos uma superioridade jurídica para compensar a inferioridade econômica [...]. Nem sempre o Estado mostrou-se bem-sucedido na tarefa. A excessiva intervenção na ordem econômica privada ocasiona distorções a longo prazo”37. 
A liberdade contratual, portanto, deve ser restringida com cautela na regulamentação dos interesses privados, buscando-se compensar a inferioridade econômica, mas sem excessos, para que não ocorra prejuízos a longo prazo na ordem econômica.

\subsection{Princípios contratuais contemporâneos: boa-fé contratual, função econômica e social do contrato}

O princípio da boa-fé encontra raízes do Direito Romano, que o traduzia simplesmente como uma noção de valor ético individual (índole subjetiva). Entretanto, foi o Direito Alemão (§ 242, BGB) que reconstruiu a noção da boa-fé, consagrando-a como um valor ou cláusula objetiva, passando a ser considerada a regra de ouro que deve estar presente sempre na interpretação e na aplicação do Direito. ${ }^{38}$

O art. 422 do Código Civil de 2002 refere-se à boa-fé objetiva, incidente nas relações obrigacionais. Para se compreender o significado dela, deve-se antes entender-se o que é a boafé subjetiva, presente no CC/1916, e que se caracteriza por um estado de consciência do agente de se comportar de acordo com o Direito, o que importa na atividade de interpretação é a intenção do sujeito, o seu estado psicológico ou a sua convicção interior.

Já a boa-fé objetiva é constitui uma inovação do atual Código Civil, constituindo um padrão de conduta em consonância com o tipo de relação entre as partes, uma cláusula geral de boa-fé objetiva, um dever de agir de acordo com determinados padrões sociais estabelecidos. Na interpretação do contrato, parte-se de um padrão de conduta comum do homem médio em determinado caso concreto, sendo considerados os aspectos sociais envolvidos.

A segurança jurídica nas relações contratuais é conquistada pela observância da lealdade e consequente confiança recíproca entre as partes, sem estas, o consentimento das partes tornase viciado, assim, “a boa-fé é tanto forma de conduta (subjetiva ou psicológica) como norma de comportamento (objetiva). Nesta última acepção, está fundada na honestidade, na retidão, na lealdade e na consideração para com os interesses do outro contraente”39 (Grifos originais).

Portanto, o princípio da boa-fé objetiva refere-se à interpretação contratual, no sentido de que a literalidade da regra contratual não deve prevalecer sobre a intenção da manifestação das partes, pois pode haver condições subentendidas, em virtude da natureza do contrato, do uso 
A noção de contrato do Direito Romano à contemporaneidade: uma análise evolutiva do sistema contratual moderno

comum ou da equidade. O intérprete, portanto, deve se preocupar mais com o espírito dos contratos do que com a sua literalidade. ${ }^{40}$

O Código Civil de 1916 não consagrou expressamente o princípio da boa-fé contratual, diferentemente do atual Código Civil, que dispõe, em seu art. 422, que os contratantes devem guardar os princípios da probidade e boa-fé, tanto na execução como na conclusão do contrato. Também, o art. 113 estatui que os negócios jurídicos devem ser interpretados conforme a boafé e os usos do lugar de sua celebração. Nessa linha, pode-se citar, ainda, o art. 187 na repreensão do ato ilícito e do abuso do direito.

Registra-se, outrossim, que "em todas essas diversas situações, a boa-fé objetiva cingese ao disciplinamento ético do comportamento dos contratantes, em relação ao outro. Não se pode, a rigor, classificar o princípio sub examine como integrante da função social do contrato"41 (Grifo original).

Diante do exposto, o que se pode reconhecer é que as partes, tanto na formação, na celebração e na execução, bem como depois da extinção do contrato, estão sujeitas aos ditames da boa-fé na interpretação e na conduta negocial. Caio Mario considera que, embora o legislador não tenha se referido expressamente sobre os períodos pré e pós-contratual, essa omissão não implica a negação da aplicação desse princípio nessas fases contratuais, cabendo, dessa forma, uma interpretação extensiva. ${ }^{42}$

Dessa forma, a boa-fé objetiva, como fator de interpretação, pode ser avaliada na responsabilidade pré-contratual como na contratual e até na pós-contratual, cabendo a jurisprudência definir esse alcance na aplicação do Direito ao caso concreto. À vista disso, concebe-se de extrema importância a observância da probidade e boa-fé, tanto na fase da criação dos deveres jurídicos para as partes, como depois de terminado o contrato, em virtude da possibilidade de sobrar-lhe efeitos contratuais residuais.

O princípio da boa-fé contratual é, portanto, uma cláusula geral, agindo como limitador da autonomia da vontade e um princípio criador de novos deveres contratuais, segundo a doutrina alemã, chamados de deveres anexos dos contratos, decorrentes do paradigma da boafé: dever de informação, dever de esclarecimento, dever de aconselhamento, dever de cooperação, e até de limitação de direitos como a vedação do venire contra factum proprium, que proíbe o comportamento contraditório; do inciviliter agere, que veda comportamentos que 
violem a dignidade humana, e da tu quoque, que representa a invocação de uma regra que a própria parte já tenha violado. ${ }^{43}$

Nesse cenário, a boa-fé objetiva se torna uma espécie de freio contra o exercício desleal de direitos, um controle que pode se apresentar por meio de diferentes figuras, entre elas: supressio, surrectio, venire contra factum proprium, tu quoque, e exceptio doli. Todos estes institutos são considerados desdobramentos da boa-fé objetiva ou figuras parcelares. ${ }^{44}$

Registra-se, ademais, que a nova visão do venire contra factum proprium à luz da teoria da confiança revela que “a vedação de conduta contraditória do contratante lastreada apenas na exigência de coerência comportamental tornou-se muito mais densa e firme sua justificação quando passou a fundar-se na 'tutela da confiança' e, consequentemente, na 'solidariedade social'" 45 . Hoje, portanto, não é a incoerência do agente que fundamenta o nemo postest venire contra factum proprium, mas a tutela da confiança, atribuindo aquele um conteúdo material, no sentido de se tornar um princípio de proibição à ruptura da confiança, por meio da incoerência. ${ }^{46}$

O conceito de boa-fé objetiva tem três funções na visão do atual Código Civil: a função de integração do negócio jurídico (art. 422), a função interpretativa (art. 113) e a função de controle dos limites do exercício de um direito (art. 187). Em qualquer situação não deve ser desprezada a boa-fé subjetiva, devendo haver, entretanto, a proeminência da boa-fé objetiva na atividade hermenêutica do juiz, cujo conteúdo sempre dependerá do caso concreto, não podendo ser fixada com rigor, em razão do sistema aberto adotado pelo Código Civil, em que a interpretação dependerá do sentido e alcance da norma em cada caso concreto.

O contrato possui, também, uma função econômica, pois está vinculado ao desenvolvimento econômico da sociedade, como gerador da circulação de riquezas. A vida moderna prescinde cada vez mais desse instrumento fomentador da economia, que proporciona a subsistência das pessoas. "Este conceito jurídico só pode ser entendido a fundo quando vinculado a uma realidade exterior, a um fato social ou econômico, a um complexo de relações que se pretenda disciplinar”47. Pode-se, nessa linha, visualizar o princípio do equilíbrio econômico do contrato nos artigos 157, 478 e 480 do CC.

De fato, o contrato constitui instrumento da liberdade de iniciativa econômica, com o objetivo de trazer segurança jurídica às transações econômicas, favorecendo a circulação de bens e serviços, beneficiando, dessa forma, não só as partes, mas também toda a sociedade. 
A noção de contrato do Direito Romano à contemporaneidade: uma análise evolutiva do sistema contratual moderno

Paralelamente a essa função econômica, aponta-se outra, a função social do contrato, que se tornou um princípio limitador dessa liberdade, pois tem como fim o interesse da sociedade.

Hoje, há prevalência dos princípios condizentes com a ordem pública em detrimento daqueles que privilegiam os interesses individuais. O contrato não é mais visto somente pelo prisma individualista, mas pelo enfoque social, podendo até ser rescindido se não buscar esse fim. A autonomia da vontade é, pois, relativizada, por leis, decisões judiciais e atos administrativos que procuram assegurar o interesse social.

A função social do contrato é um princípio moderno, decorrente da função social da propriedade, consagrada no art. $5^{\circ}$, XXIII, e art. 170, III, da CF, e que surge para acrescer aos princípios clássicos, justapondo-se a eles, desafiando-os e até impedindo que prevaleçam em determinadas situações, em que o interesse social é maior. Em nossos dias, o contrato é visto como fator de alteração da realidade social, sendo colocado como instrumento de cooperação que deve atender tanto os interesses das partes contratantes quanto da sociedade.

Portanto, a função social do contrato, na acepção mais moderna, representa o reconhecimento da inserção do contrato no meio social e da sua função de influência na vida das pessoas no sentido de possibilitar um maior controle em suas atividades. ${ }^{48}$

Assim, esse princípio somente restará aplicado se o contrato trouxer um equilíbrio social; em outras palavras, se for estabelecido de forma justa para os indivíduos e para a sociedade. ${ }^{49}$

Contrastando com o sentido individualista do Código Civil de 1916, o atual Código reflete a importância dos valores coletivos sobre os individuais, pelo princípio da socialidade por ele adotado. Nessa concepção, dispõe em seu art. 421 que a liberdade de contratar será exercida em razão e nos limites da função social do contrato. ${ }^{50}$

Assim, mesmo que a lei civil não tenha definido a função social do contrato, expressa em algumas normas a importância da moral e da equidade nas relações contratuais, como no art. 422, que representa a consagração da boa-fé objetiva. ${ }^{51}$

Seguindo o compasso da Constituição Federal, o Código Civil de 2002 inseriu a cláusula geral da função social, sendo o seu reconhecimento consequência dos imperativos constitucionais relativos à justiça que deve presidir a ordem econômica. Referida cláusula concretiza-se quando é satisfeito o princípio da solidariedade social (art. $3^{\circ}$, I, CF), a justiça social (art. 170, caput), a livre iniciativa (art. $1^{\circ}$, IV) e, principalmente, a dignidade da pessoa 
humana (art. $1^{\circ}$, III); encontrando fundamento de validade na função social da propriedade privada (art. 170, III, CF). ${ }^{52}$

Registra-se, ainda, que a relatividade dos efeitos contratuais é mitigada pela função social do contrato. "O reconhecimento de uma função social para o contrato atinge, em cheio, a noção de relatividade, pois o negócio deixa de ser algo que interessa apenas às partes, podendo suscitar, ainda que de maneira oblíqua ou reflexa, efeitos para terceiros” ${ }^{53}$.

Denota-se, portanto, uma nova ordem jurídica contratual, em que novos valores ganham relevo. Boa-fé, equidade, justiça e confiança, aliadas à satisfação dos interesses das partes contratantes e, consequentemente, à autonomia da vontade, são conformadas com a função social do contrato. A solidariedade social foi resgatada pelo princípio da função social do contrato, pois o contrato é, hoje, um instrumento de cooperação que deve atender tanto aos interesses dos contratantes quanto os da sociedade. Destacam-se, com efeito, os seguintes princípios sociais do contrato: a função social, a equivalência material e boa-fé objetiva. ${ }^{54}$

Outrossim, frisa-se que a análise da função social do contrato deve ser feita dentro de um panorama sistêmico, levando em consideração os valores constitucionais e o Código Civil, pois o contrato deixou de ser um negócio jurídico isolado, estático, mas sim um instituto dinâmico que deve acompanhar as mudanças sociais e servir de instrumento de equilíbrio individual e social. Por conseguinte, “o Código Civil cumprirá sua vocação de pacificação social se for efetivamente iluminado pelos valores maiores que foram projetados nas normas constitucionais, notadamente nos princípios”55, os princípios tradicionais e os modernos, como a boa-fé objetiva e a função econômica e social do contrato, todos conformados à nova realidade contemporânea.

A justiça material, portanto, deve ser a busca maior do Direito Civil contratual, em um equilíbrio constante entre a autonomia da vontade e a função social do contrato, sem se esquecer a boa-fé objetiva como norma de conduta e de interpretação dos contratos, ainda mais no cenário da globalização econômica mundial.

\section{CONCLUSÃO}

A teoria contratual evoluiu do Direito Romano, formalista a princípio e consensualista, no final do Império Romano, alcançou a Idade Moderna, consagrando o princípio da liberdade 
A noção de contrato do Direito Romano à contemporaneidade: uma análise evolutiva do sistema contratual moderno

contratual e do consensualismo, impulsionando a doutrina civilista. A conceituação moderna de contrato, porém, foi sendo mitigada em função do advento de movimentos que se denominaram Estado Social, berço do dirigismo contratual pelo Estado intervencionista, ocasionando a massificação dos contratos, no final do século XIX e século XX, surgindo daí novas formas contratuais.

Denota-se um progresso quantitativo e qualitativo do contrato: quantitativo, porque os contratos se tornaram mais numerosos, surgindo-se mais figuras contratuais; e qualitativo, em razão do aperfeiçoamento e desenvolvimento de novos princípios disciplinadores das relações contratuais.

Toda essa evolução fez com que o Código Civil brasileiro de 2002 consagrasse, além dos princípios tradicionais da autonomia da vontade, da força obrigatória, da intangibilidade contratual e da relatividade de seus efeitos; os princípios da boa-fé objetiva, da função social do contrato e do equilíbrio econômico do contrato. Dessa forma nasce uma nova forma de tratamento do contrato, fruto de todo o desenvolvimento da teoria contratual ao longo do tempo.

No Estado Democrático de Direito, adotado pela Constituição Federal Brasileira de 1988, em seu artigo $1^{\circ}$, em que se adota o fundamento da livre iniciativa econômica (art. 170), ressaltase a extrema importância do contrato na sociedade em questão, em que a liberdade de contratar não impede a ação interventiva e diretiva do Estado, no sentido de regular as relações contratuais, para haver o equilíbrio econômico.

Em conclusão, registra-se que a evolução da sistemática contratual encontrou raízes no Direito Romano, berço de nossa ordem jurídica e de nosso sistema contratual. Por isso, compreende-se que o estudo de seus institutos pode nos oferecer uma melhor compreensão dos atuais, não apenas com relação à origem, mas no que se refere à evolução ao longo do tempo até nossos dias, numa constante interação histórica e sistêmica.

\section{BIBLIOGRAFIA}

AZEVEDO, Álvaro Villaça. Teoria geral dos contratos típicos e atípicos: curso de Direito Civil. São Paulo: Atlas, 2002. 
DAVID, René. Os grandes sistemas do Direito contemporâneo. Tradução Hermínio A. Carvalho. 3. ed. São Paulo: Martins Fontes, 1996.

DELGADO, José Augusto. O contrato no Código Civil e a sua função social. Revista Jurídica Notadez. Porto Alegre, ano 52, n. 322, p. 07-28, ago. 2004.

FIÚZA, Cezar. Direito Civil: curso completo. 8. ed. revista, atualizada e ampliada. Belo Horizonte: Del Rey, 2004.

GRAU, Eros Roberto. A ordem econômica na Constituição de 1988: interpretação e crítica. 12. ed. revista e atualizada. São Paulo: Malheiros, 2007.

GOMES, Daniela Vasconcellos. Os princípios da boa-fé e da função social do contrato e a teoria contratual contemporânea. Revista de Direito Privado. São Paulo, n. 26, p. 77-104, abr.jun. 2006.

GOMES, Orlando. Contratos. 17. ed. atualização e notas de Humberto Theodoro Júnior. Rio de Janeiro: Forense, 1997.

GONÇALVES, Carlos Roberto. Direito Civil brasileiro: contratos e atos unilaterais. São Paulo: Saraiva, 2017, v.3.

GUTIÉRREZ, Ricardo Panero. Derecho Romano. 3 ed. Valencia: Tirant Lo Blanch, 2004.

KANT, Immanuel. Crítica da razão prática. São Paulo: Martin Claret, 2003.

LOBO, Paulo. A constitucionalização do Direito Civil brasileiro. In: TEPEDINO, Gustavo (Organizador). Direito Civil contemporâneo: novos problemas à luz da legalidade constitucional. São Paulo: Atlas, 2008.

LOUREIRO, Luiz Guilherme. Contratos no novo Código Civil: Teoria Geral e Contratos em Espécie. 2. ed. revista, atualizada e ampliada. São Paulo: Editora Método, 2004.

MATTIETTO, Leonardo. Função Social e Relatividade do Contrato: Um Contraste entre Princípios. Revista Jurídica Notadez. Porto Alegre, ano 54, n. 342, p. 29-40, abr. 2006.

MOREIRA ALVES, José Carlos. Direito Romano. 14. ed. Rio de Janeiro: Forense, 2007. 
A noção de contrato do Direito Romano à contemporaneidade: uma análise evolutiva do sistema contratual moderno

PEREIRA, Caio Mário da Silva. Instituições de Direito Civil: Contratos. 18. ed. revista e atualizada por Caitlin Mulholland. Rio de Janeiro: Forense, 2014, v. 3.

RODRIGUES JUNIOR, Otavio Luiz. Revisão judicial dos contratos: autonomia da vontade e teoria da imprevisão. 2. ed. revista, ampliada e atualizada. São Paulo: Atlas, 2006.

RODRIGUES, Silvio. Direito Civil: dos contratos e das declarações unilaterais da vontade. 30. ed. atualizada de acordo com o Código Civil de 2002. São Paulo: Saraiva, 2004, v. 3, p. 16

SANTOS JUSTO, Antônio. Direito Privado Romano. 4. ed. Coimbra: Editora Coimbra, 2008, V. 4.

SCHREIBER, Anderson. A proibição de comportamento contraditório: tutela da confiança e venire contra factum proprium. 2. ed. Rio de Janeiro: Renovar, 2007.

THEODORO JÚNIOR, Humberto. O contrato e sua função social: a boa-fé objetiva no ordenamento jurídico e a jurisprudência contemporânea. 4. ed. Rio de Janeiro: Forense, 2014.

VENOSA, Silvio de Salvo. Direito Civil: teoria geral das obrigações e teoria geral dos contratos. 15. ed. São Paulo: Atlas, 2015, v. 2.

\footnotetext{
${ }^{1}$ DAVID, René. Os grandes sistemas do Direito contemporâneo. Tradução Hermínio A. Carvalho. 3. ed. São Paulo: Martins Fontes, 1996, p. 27.

${ }^{2}$ A história externa se refere aos períodos históricos, e a história interna representa o estudo das instituições de Direito Privado. MOREIRA ALVES, José Carlos. Direito Romano. 14. ed. Rio de Janeiro: Forense, 2007 , p. 01.

${ }^{3}$ GUTIÉRREZ, Ricardo Panero. Derecho Romano. 3 ed. Valencia: Tirant Lo Blanch, 2004, p. 456.

${ }^{4}$ GUTIÉRREZ, Ricardo Panero. Derecho Romano. 3 ed. Valencia: Tirant Lo Blanch, 2004, p. 513-515.

${ }^{5}$ SANTOS JUSTO, Antônio. Direito Privado Romano. 4. ed. Coimbra: Editora Coimbra, 2008, v. 4, p. 183.

${ }^{6}$ AZEVEDO, Álvaro Villaça. Teoria geral dos contratos típicos e atípicos: curso de Direito Civil. São Paulo: Atlas, 2002, p. 22.

${ }^{7}$ GUTIÉRREZ, Ricardo Panero. Derecho Romano. 3 ed. Valencia: Tirant Lo Blanch, 2004, p. 533-534.

${ }^{8}$ GUTIÉRREZ, Ricardo Panero. Derecho Romano. 3 ed. Valencia: Tirant Lo Blanch, 2004, p. 533.

${ }^{9}$ PEREIRA, Caio Mário da Silva. Instituições de Direito Civil: Contratos. 18. ed. revista e atualizada por Caitlin Mulholland. Rio de Janeiro: Forense, 2014, v. 3, p. 16.

${ }^{10}$ MOREIRA ALVES, José Carlos. Direito Romano. 14. ed. Rio de Janeiro: Forense, 2007, p. 472.

${ }^{11}$ PEREIRA, Caio Mário da Silva. Instituições de Direito Civil: Contratos. 12. ed. revista e atualizada de acordo com o Código Civil de 2002, por Regis Fichtner. Rio de Janeiro: Forense, 2005, v. 3, p. 569.

${ }^{12}$ MOREIRA ALVES, José Carlos. Direito Romano. 14. ed. Rio de Janeiro: Forense, 2007, p. 472.

${ }^{13}$ VENOSA, Silvio de Salvo. Direito Civil: teoria geral das obrigações e teoria geral dos contratos. 15. ed. São Paulo: Atlas, 2015, v. 2, p. 399.

${ }^{14}$ PEREIRA, Caio Mario da Silva. Instituições de Direito Civil: contratos. 12. ed. revista e atualizada de acordo com o Código Civil de 2002, por Regis Fichtner. Rio de Janeiro: Forense, 2005, v. 3, p. 570.

15 Sendo o contrato inspirado no acordo de vontades e sendo expressão da vontade livre dos contratantes, não poderiam estipular um acordo que ferisse o princípio da justiça. O contrato fundava-se no princípio da liberdade,
} 
que se fundamentava na convicção de que assim se estabelecia o equilíbrio econômico. PEREIRA, Caio Mario da Silva. Instituições de Direito Civil: contratos. 12. ed. revista e atualizada de acordo com o Código Civil de 2002, por Regis Fichtner. Rio de Janeiro: Forense, 2005, v. 3, p. 571.

${ }^{16}$ RODRIGUES JUNIOR, Otavio Luiz. Revisão judicial dos contratos: autonomia da vontade e teoria da imprevisão. 2. ed. revista, ampliada e atualizada. São Paulo: Atlas, 2006, p. 14.

17 GOMES, Orlando. Contratos. 17. ed. atualização e notas de Humberto Theodoro Júnior. Rio de Janeiro: Forense, 1997, p. 5.

${ }^{18}$ FIÚZA, Cezar. Direito Civil: curso completo. 8. ed. revista, atualizada e ampliada. Belo Horizonte: Del Rey, 2004, p. 377.

${ }^{19}$ PEREIRA, Caio Mario da Silva. Instituições de Direito Civil: contratos. 12. ed. revista e atualizada de acordo com o Código Civil de 2002, por Regis Fichtner. Rio de Janeiro: Forense, 2005, v. 3, p. 571.

${ }^{20}$ Entre as modificações na tipologia contratual do Código de 1916, podem ser citados os institutos da edição, da representação dramática e o contrato de seguro. E como resquícios romanos nesse código, têm-se os contratos de mútuo, comodato, depósito, que continuaram a ser reais, se perfazendo com a tradição da coisa, em contraposição à moderna doutrina contratual, que os considera consensuais. PEREIRA, Caio Mario da Silva. Instituições de Direito Civil: contratos. 12. ed. revista e atualizada de acordo com o Código Civil de 2002, por Regis Fichtner. Rio de Janeiro: Forense, 2005, v. 3, p. 571.

${ }^{21}$ Novos tipos de contrato do Código Civil de 2002: contratos de comissão, transporte, corretagem, agência, distribuição, venda com reserva de domínio, venda sobre documentos e estimatório. PEREIRA, Caio Mario da Silva. Instituições de Direito Civil: contratos. 12. ed. revista e atualizada de acordo com o Código Civil de 2002, por Regis Fichtner. Rio de Janeiro: Forense, 2005, v. 3, p. 571.

${ }^{22}$ GOMES, Orlando. Contratos. 17. ed. atualização e notas de Humberto Theodoro Júnior. Rio de Janeiro: Forense, 1997.

${ }^{23}$ PEREIRA, Caio Mário da Silva. Instituições de Direito Civil: Contratos. 18. ed. revista e atualizada por Caitlin Mulholland. Rio de Janeiro: Forense, 2014, v. 3, p. 10-28.

${ }^{24}$ KANT, Immanuel. Crítica da razão prática. São Paulo: Martin Claret, 2003, p. 43.

${ }^{25}$ RODRIGUES JUNIOR, Otavio Luiz. Revisão judicial dos contratos: autonomia da vontade e teoria da imprevisão. 2. ed. revista, ampliada e atualizada. São Paulo: Atlas, 2006, p. 19.

${ }^{26}$ GOMES, Orlando. Contratos. 17. ed. atualização e notas de Humberto Theodoro Júnior. Rio de Janeiro: Forense, 1997, p. 22.

${ }^{27}$ PEREIRA, Caio Mário da Silva. Instituições de Direito Civil: Contratos. 18. ed. revista e atualizada por Caitlin Mulholland. Rio de Janeiro: Forense, 2014, v. 3, p. 18.

${ }^{28}$ O Direito Romano já proclamava a regra da obrigatoriedade das convenções, porém, com caráter absoluto. Hoje, a regra subsiste, mas não tão absoluta, existindo ressalvas ou relatividade de regra. PEREIRA, Caio Mário da Silva. Instituições de Direito Civil: Contratos. 18. ed. revista e atualizada por Caitlin Mulholland. Rio de Janeiro: Forense, 2014, v. 3, p. 13 e 19.

${ }^{29}$ VENOSA, Silvio de Salvo. Direito Civil: teoria geral das obrigações e teoria geral dos contratos. 15. ed. São Paulo: Atlas, 2015, v. 2, p. 411.

${ }^{30}$ RODRIGUES, Silvio. Direito Civil: dos contratos e das declarações unilaterais da vontade. 30. ed. atualizada de acordo com o Código Civil de 2002. São Paulo: Saraiva, 2004, v. 3, p. 17-18.

31 RODRIGUES JUNIOR, Otavio Luiz. Revisão judicial dos contratos: autonomia da vontade e teoria da imprevisão. 2. ed. revista, ampliada e atualizada. São Paulo: Atlas, 2006, p. 17.

${ }^{32}$ Revogado art. 85, CC/1916. Ainda, o art. 81, CC/1916 aduzia que "todo ato lícito, que tenha por fim imediato adquirir, resguardar, transferir, modificar ou extinguir direitos, se denomina ato jurídico”. Na linha do Código Civil de Clóvis Beviláqua, “a vontade tudo cria, modifica ou extingue no mundo do direito”. RODRIGUES JUNIOR, Otavio Luiz. Revisão judicial dos contratos: autonomia da vontade e teoria da imprevisão. 2. ed. revista, ampliada e atualizada. São Paulo: Atlas, 2006, p. 17.

33 RODRIGUES JUNIOR, Otavio Luiz. Revisão judicial dos contratos: autonomia da vontade e teoria da imprevisão. 2. ed. revista, ampliada e atualizada. São Paulo: Atlas, 2006, p. 21.

${ }^{34}$ RODRIGUES, Silvio. Direito Civil: dos contratos e das declarações unilaterais da vontade. 30. ed. atualizada de acordo com o Código Civil de 2002. São Paulo: Saraiva, 2004, v. 3, p. 16.

${ }^{3}$ PEREIRA, Caio Mário da Silva. Instituições de Direito Civil: Contratos. 18. ed. revista e atualizada por Caitlin Mulholland. Rio de Janeiro: Forense, 2014, v. 3, p. 24.

${ }^{36}$ PEREIRA, Caio Mário da Silva. Instituições de Direito Civil: Contratos. 18. ed. revista e atualizada por Caitlin Mulholland. Rio de Janeiro: Forense, 2014, v. 3, p. 25. 
${ }^{37}$ VENOSA, Silvio de Salvo. Direito Civil: teoria geral das obrigações e teoria geral dos contratos. 15. ed. São Paulo: Atlas, 2015, v. 2, p. 410.

${ }^{38}$ O Código Civil Alemão (BCG), no final do século XIX e no início do século XX, dispôs em seu § 242: "O devedor está adstrito a realizar a prestação tal como a exija a boa-fé, em consideração aos costumes do tráfego". Entretanto, somente após a Primeira Guerra Mundial, que a boa-fé objetiva do § 242 do BCB, se tornou plena de realização.

${ }^{39}$ GONÇALVES, Carlos Roberto. Direito Civil brasileiro: contratos e atos unilaterais. São Paulo: Saraiva, 2017, v. 3 , p. 56.

40 GOMES, Orlando. Contratos. 17. ed. atualização e notas de Humberto Theodoro Júnior. Rio de Janeiro: Forense, 1997, p. 42.

${ }^{41}$ THEODORO JÚNIOR, Humberto. O contrato e sua função social: a boa-fé objetiva no ordenamento jurídico e a jurisprudência contemporânea. 4. ed. Rio de Janeiro: Forense, 2014, p. 28.

${ }^{42}$ PEREIRA, Caio Mário da Silva. Instituições de Direito Civil: Contratos. 18. ed. revista e atualizada por Caitlin Mulholland. Rio de Janeiro: Forense, 2014, v. 3, p. 19.

${ }^{43}$ PEREIRA, Caio Mário da Silva. Instituições de Direito Civil: Contratos. 18. ed. revista e atualizada por Caitlin Mulholland. Rio de Janeiro: Forense, 2014, v. 3, p. 20.

${ }^{44}$ A supressio e a surrectio configuram, ambas, uma violação da boa-fé pelo não exercício desleal de direitos, havendo uma sequência de dois comportamentos, em que o primeiro é sempre omissivo e o segundo sempre comissivo - entre o primeiro e o segundo, haverá uma omissão no exercício de um direito que se qualifica pelo decurso do tempo. Já o venire contra factum proprium, instituto que nasceu na Idade Média, na Inglaterra, constitui, uma sequência de lógica de dois comportamentos, que se observados isoladamente se mostrariam lícitos, mas que se analisados em conjunto, o segundo comportamento se torna ilícito pela incoerência comportamental. $\mathrm{O}$ termo tu quoque visa evitar que uma das partes da relação negocial surpreenda a outra, causando-lhe prejuízo, sendo, também, uma sequência lógica de dois comportamentos, em que o primeiro comportamento (ilícito culposo) termina gerando uma violação da confiança e arrastando o segundo (lícito) para a ilicitude. Significa que se uma das partes violou uma norma jurídica, não poderá aproveitar-se dessa situação posteriormente, sem a caracterização de abuso do direito. Como exemplo do tu quoque, tem-se a exceptio non adimplet contractus (exceção do contrato não cumprido), que significa que só se pode exigir a prestação da outra parte, se a parte tiver cumprido a sua contraprestação, constituindo uma defesa indireta de mérito, prevista nos artigos 476 e 477 do CC. ${ }^{45}$ É de registrar, também, que "o venire contra factum proprium, nessa ordem de ideias, corresponde a máxima jurídica que não se restringe ao direito das obrigações, mas que transita amplamente entre o direito substancial e o processual”. THEODORO JÚNIOR, Humberto. O contrato e sua função social: a boa-fé objetiva no ordenamento jurídico e a jurisprudência contemporânea. 4. ed. Rio de Janeiro: Forense, 2014, p. 60 e 79.

${ }^{46}$ SCHREIBER, Anderson. A proibição de comportamento contraditório: tutela da confiança e venire contra factum proprium. 2. ed. Rio de Janeiro: Renovar, 2007, p. 101.

${ }^{47}$ LOUREIRO, Luiz Guilherme. Contratos no Novo Código Civil: Teoria Geral e Contratos em Espécie. 2. ed. revista, atualizada e ampliada. São Paulo: Editora Método, 2004, p. 52.

${ }^{48}$ PEREIRA, Caio Mário da Silva. Instituições de Direito Civil: Contratos. 18. ed. revista e atualizada por Caitlin Mulholland. Rio de Janeiro: Forense, 2014, v. 3, p. 13.

${ }^{49}$ DELGADO, José Augusto. O Contrato no Código Civil e a sua função social. Revista Jurídica Notadez. Porto Alegre, ano 52, n. 322, ago. 2004, p. 15.

${ }^{50}$ PEREIRA, Caio Mário da Silva. Instituições de Direito Civil: contratos. 18. ed. revista e atualizada por Caitlin Mulholland. Rio de Janeiro: Forense, 2014, v. 3, p. 12.

${ }^{51}$ Em normas do Código Civil também transparece a preocupação do legislador com os valores sociais, aos quais se poderá aplicar a vertente da função social do contrato, como o art. 156 (estado de perigo); art. 157 (instituto da lesão), que consagra a rescisão do contrato lesivo; art. 424 (contrato de adesão); parágrafo único do art. 473 (resilição unilateral do contrato); art. 884 (enriquecimento sem causa), entre outras. Pode-se, também, ainda, citar o art. 51, CDC, em que se poderá aplicar a função social do contrato, para impedir que a liberdade contratual se manifeste sem freios.

${ }^{52}$ Nessa esteira, como bem assevera Eros Roberto Grau, "à propriedade dotada de função individual respeita o art. $5^{\circ}$, XXII do texto constitucional; de outra parte, [...] à propriedade função social, e que diretamente importa à ordem econômica - a propriedade dos bens de produção - respeita o princípio inscrito no art. 170, III”. GRAU, Eros Roberto. A ordem econômica na Constituição de 1988: interpretação e crítica. 12. ed. revista e atualizada. São Paulo: Malheiros, 2007, p. 247. 
53 MATTIETTO, Leonardo. Função social e relatividade do contrato: um contraste entre princípios. Revista Jurídica Notadez. Porto Alegre, ano 54, n. 342, abr. 2006, p. 34.

54 “O princípio da equivalência material é manifestação da busca da efetiva igualdade entre as partes. Quando a igualdade jurídico-formal característica da concepção liberal mostrou-se insuficiente para garantir o equilíbrio das prestações nos contratos, esse princípio passou a ter grande importância na teoria contratual. A equivalência material busca harmonizar os interesses das partes envolvidas, e realizar o equilíbrio real das prestações em todo o processo obrigacional [...] esse princípio relativiza o princípio clássico do pacta sunt servanda, [...]. Isso porque com o reconhecimento de que a simples igualdade formal não basta para se alcançar a justiça contratual, foi preciso levar em consideração as condições reais para a execução do contrato realizado. Assim, o contrato continua obrigatório, mas à medida que se mantenha dos limites de equilíbrio entre as prestações” (Grifo original). GOMES, Daniela Vasconcellos. Os princípios da boa-fé e da função social do contrato e a teoria contratual contemporânea. Revista de Direito Privado. São Paulo, n. 26, abr./jun. 2006, p. 97-98.

${ }^{55}$ LOBO, Paulo. A constitucionalização do Direito Civil brasileiro. In: TEPEDINO, Gustavo (Organizador). Direito Civil contemporâneo: novos problemas à luz da legalidade constitucional. São Paulo: Atlas, 2008, p. 23. 